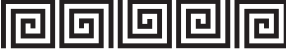

PHILOLOGIA CLASSICA

\title{
BILINGUAL WRITINGS ON BILINGUAL WRITINGS: J. WIDEKINDI'S LETTERS TO M. G. DE LA GARDIE
}

\author{
Arsenij Vetushko-Kalevich
}

St. Petersburg State University, 7-9, Universitetskaya nab., St. Petersburg, 199034, Russian Federation; st020343@student.spbu.ru

Lunds Universitet, Språk- och litteraturcentrum,

Helgonabacken 12, Box 201, 22100 Lund, Sverige; arsenii.vetushko-kalevich@klass.lu.se

The collection of J. Widekindi's letters to M.G. De la Gardie, preserved in the National Archives of Sweden, has not received decent attention in the research concerning the origins of Widekindi's main work, Historia Belli Sveco-Moscovitici Decennalis, which describes the events of the Russian Time of Troubles and the Ingrian War. Especially important in this respect is the last of the eleven letters, dated 15th March 1672 and dealing almost exclusively with Historia. From it we learn that the original text of this bilingual work was written in Latin (although the Swedish version was published first). Hence the status of the versions: the Swedish edition from 1671 is a translation, hastily made by several persons, while the Latin edition from 1672 is a revised and incomplete text of the original written by Widekindi himself. With the help of another letter we find out that Widekindi had started working on the book as early as by 1661 . His main scope, clearly indicated in yet other letters, was to glorify his patron's father, Jacob De la Gardie. But M. G. De la Gardie, who was aware of the project for a long time, gave his support to it only in 1666 (or later) - probably because it became quite relevant for his foreign policy. From the letters we also find out that Widekindi took care of Chancellor Axel Oxenstierna's library from the middle of the 1650s. This fact, along with the extensive usage of one of Oxenstierna's drafts in the first book of Historia, gives a clue to where Widekindi got acquainted with many of his sources. The catalogue of Oxenstierna's book collection shows this suggestion to be correct.

Keywords: Time of Troubles, Ingrian War, Swedish Neo-Latin, 17th century historiography, Rossica, Johannes Widekindi, Magnus Gabriel De la Gardie.

The period of social and political turbulence in Russia in the beginning of the 17th century is known as the Time of Troubles. As it involved Polish and Swedish intervention, the events that took place in the years 1605-1618 are described in a wide range of sources written, apart from Russian, in Swedish, Polish, German - and Latin.

The history of the Swedish-Muscovite ten-years war (Swed. Thet Swenska i Ryssland Tijo åhrs Krijgz-Historie, Lat. Historia belli Sveco-Moscovitici decennalis, hereafter referred to as Historia) by the Swedish historiographer of the Realm Johannes Widekindi (ca 16201678), published in Swedish in 1671 and in Latin in 1672, belongs to the most important

(C) St. Petersburg State University, 2016 
sources on the Russian Time of Troubles in general and on the Ingrian war (1610-1617) in particular. Apart from Linnaeus' and Swedenborg's writings, the Latin version of the book is the only large piece of Swedish Neo-Latin literature ever translated into Russian ${ }^{1}-$ thanks to the scholars from the Leningrad Institute of History in the 1930s and their colleagues (mostly from Moscow) in the 1980s, who, apart from editing the translation, provided it with a rich historical commentary and an apparatus where differences between Latin and Swedish versions are enumerated.

Kari Tarkiainen, a famous specialist in Swedish 17th century historiography, after quoting a passage from Widekindi's letter to his patron, Chancellor of Sweden Magnus Gabriel De la Gardie, where the book is mentioned, states: "it is not known how the work was effected". 2 This is, however, a bit too pessimistic. The small collection of letters, as it turns out, can tell us about the history of Historia more than we could wish.

There are 11 letters preserved in the Swedish National Archives (De la Gardieska samlingen, E1596), five of them in Latin and six in Swedish. The first one was written in 1661, the last one in 1672. This last letter deals almost exclusively with Historia; its full text can be found in the Appendix to the article. Previously the letters have been studied by Tarkiainen (who for some reason quotes passages only from those written in Swedish), Theodor Westrin ${ }^{3}$ (who paraphrases them, quite briefly, as is natural for an encyclopedia entry; it will be discussed further), and Sven Edlund ${ }^{4}$ (who is interested only in the letter treating the organisation of the Stockholm Gymnasium), so I found it necessary to begin with a synopsis of all of them with particular emphasis on the references to the Historia.

\section{Letter 1, 8th January 1661, Latin ${ }^{5}$}

We become immediately aware that Widekindi and De la Gardie have never met before: "Post novi anni felix auspicium et solennem apprecationem decenter contestatam, illustriss<imae > Excellentiae Tuae vultum subire audet haec ignoti nominis Epistola...”. Widekindi pays compliments to De la Gardie's virtues and then describes his own background. Seven years have passed since he returned to Sweden and became a teacher at the Stockholm Gymnasium. The late Chancellor of Sweden Erik Axelsson Oxenstierna (1624-1656) committed to Widekindi to take care of his father's (i. e. the great Axel Oxenstierna's) library. Widekindi found there a lot of material concerning relations between Sweden and Poland and got a wish to write a history of these relations beginning with the death of John III. In 1659 he presented this project to Charles X Gustav and got an approval. However, early in the next year the king died, and besides that, Widekindi found out that Habaeus and Loccenius ${ }^{6}$ were already working on the same subject. Thus he switched to some other material ("arripui hunc, quem transmissa pagina intimat, laborem,

${ }^{1}$ Видекинд, Ю.История десятилетней шведско-московитской войны. Перевод С.А.Аннинского, А. М. Александрова / Под ред. В. Л.Янина, А. Л. Хорошкевич. Москва, 2000. The resulting translation merges both Latin and Swedish versions into one text.

2 Tarkiainen 1986, 184.

3 Westrin 1921, 263-264.

${ }^{4}$ Edlund 1954, 256.

${ }^{5}$ Whenever the place is indicated at all (and that is the case in № 1,2, 3, 9 and 11), the letters are sent from Stockholm.

${ }^{6}$ Christian Hab(b)aeus (ca 1627-1680), ennobled in 1664 as Lichtenstern, was a diplomate and a Royal secretary. His only known work is Ursachen, wodurch eigentlich die Königl. Mayst. zu Schweden bewogen worden, den Hertzog von Churland ausz seinem Fürstenthumb hinweg in Verwahrung zu ziehen from 1659, also translated into Latin. Johannes Loccenius (1598-1677) was a German scholar in Swedish office; 
eum magna ex parte absolvi, sed ita, ut multa restent"). Now he wants to finish the book, but his financial resources are scarce. Fortunately, some profitable position in Stockholm is vacant ("tale munus, cui studia mea magna ex parte dicata"), and Widekindi asks for De la Gardie's help in obtaining it. He is sure that, whatever his duties at this post may be, he will still have enough time for yet another project ("alteri cogitato labori, si approbaris, contexendo").

\section{Letter 2, 2nd March 1662, Latin}

Widekindi expresses his deep concern about De la Gardie’s illness ("post amissionem tot Patronorum, ${ }^{7}$ non poteram non spiritu deijci") and looks forward to seeing him in good health again. He has looked through "Messenianum scriptum", ${ }^{8}$ sent to him by De la Gardie. The attempt of Messenius is, says Widekindi, praiseworthy, but a lot has to be corrected both in style ("non satis latini et florentis seculi cultum redolens") and in content. The history of most ancient times has to look more convincing. However, what does not seem too absurd, may be left intact: Sweden has as much right to construct its glorious past as many other nations, from Assyrians to Danes, who use extremely doubtful writings of a certain Berosus ${ }^{9}$ to achieve this goal: "detur et haec licentia nobis, ac veneratio antiquitati". ${ }^{10}$ There follows a quotation from Seneca (Dial. 12, 7, 5): "Assiduus est humani generis discursus..." etc. Widekindi is ready to discuss Messenius' work when he meets De la Gardie personally.

\section{Letter 3, 17th July 1662, Latin}

After having experienced De la Gardie's benevolence, Widekindi turned back to his former interest in historiography, which he had temporarily left aside for legal studies after the death of Charles X Gustav. Now he is mainly occupied with Lumen Chronologicum, ${ }^{11}$ but works on another historiographical writing as well: "Caepi quoque tumultuum Sveoet Moscho-Poloniensium initia historico charactere signare". His other plans include notes on old Swedish law, critical notes on Messenius' work and its edition. But he has neither proper status nor salary for pursuing his projects, whereas making too long a pause in the work is risky: after all, both Widekindi and his patron De la Gardie are mortal. If De la Gardie wants this work to be continued, he had better provide Widekindi with a decent position. His current one requires, among other things, glorifying the deeds of the royal

of all his numerous works Widekindi seems to allude to what was to become Historia Rerum Svecicarum, published in 1662 (enlarging the first edition from 1654 with the events from the previous century).

7 Erik Axelsson Oxenstierna died 1656, his brother Johan Oxenstierna 1657, and king Charles X Gustav 1660 .

${ }^{8}$ Johannes Messenius (1579-1636) was a Swedish historiographer; in 1616 he was accused of participating in a conspiracy and imprisoned. His main work is the huge Scondia illustrata, written in prison and finally published in $1700-1705$ by Johan Peringskiöld. It is probably this manuscript that Widekindi is talking about.

9 I. e. the famous forgeries of Annius of Viterbo. In Swedish historiography they became quite popular since Johannes Magnus' Historia de omnibus Gothorum Sveonumque regibus (1554), and Widekindi was actually the first in Sweden to put them into doubt openly, namely in his Lumen Chronographicum, published in 1664 (see Wifstrand Schiebe 1992, 56-60). Thus the letter provides us with a sort of background to Widekindi's harsh judgment, expressed two years later.

${ }^{10}$ Probably an allusion to Livy's preface, with a similar wording (Livy has "datur haec venia antiquitati") and a similar context.

${ }^{11}$ Sic. The work was published as Lumen Chronographicum, but Widekindi's works from 1666 are entitled Continuatio Luminis Chronologici and Introductio in Lumen Chronologicum. 
family on different occasions, but he does not number it among his merits and does not get paid for it either. He does not want to attend funerals, as is common for some of his colleagues ("more aliorum hic in funera prodire, et pudet et dedecet honestatis cultorem"). Widekindi would be grateful for any position De la Gardie can help him to get.

\section{Letter 4, 1st March ${ }^{12}$ 1663, Swedish}

De la Gardie has promised Widekindi the position of a historiographer. Therefore, Widekindi asks him to provide him with an official document that would give him access to the State archives, for he will need to get prepared for his new duties. He is also ready with his Lumen Chronologicum, but complains about the high costs required by the printer. Widekindi suggests that his expenses may be covered by the Gymnasium's salary of Tolstadius, the deceased lecturer in theology.

\section{Letter 5, 2nd March 1663, Swedish}

Widekindi begs pardon for writing to De la Gardie too often. He has found out that Tolstadius' salary for the year 1662 had been paid to Zacharias Klingius. ${ }^{13}$ Thus he asks to get Tolstadius' salary for the year 1663 instead. Once again Widekindi asks De la Gardie for an improvement of his condition. He is tired of working as a teacher in a gymnasium and of all the speeches he has to hold "nomine publico" without getting a penny for it. $\mathrm{He}$ has just begun working on a history of ancient Swedish law as well as on the "pragmatic history of our affairs with Poles and Muscovites", where the deeds of De la Gardie's deceased father "shine notably" ("märkeligen liusa"). He does not conceal that the subject is chosen deliberately, putting a quotation from Livy $(4,35,7)$ : "Eo nempe laborem lubenter impendimus, unde honos et emolumentum speratur".

\section{Letter 6, 3rd June $1663(?),{ }^{14}$ Latin}

Widekindi is still looking forward to getting the historiographer's position promised to him by De la Gardie. A conversation on his duties and salary may wait until De la Gardie has time for it, but now that Widekindi is ready with his Lumen Chronologicum, he needs to get access to the archives as soon as possible, to check some documents concerning both ancient and more recent history. He compares his work to a geographical map, but applied to history. As for the work of Messenius, he does not know if De la Gardie read his letter with a review of it, so he briefly repeats its contents. Widekindi leaves it to De la Gardie's own decision whether he should go on with Messenius, "vel an propiora seculo nostro mihi committere placeat".

\section{Letter 7, 29th January 1665, Swedish}

Widekindi reminds De la Gardie about his wish that the salary of Nicolaus Salanus, ${ }^{15}$ who has left the Gymnasium, should be paid to one of his students, who helps him with

12 This date is given in Tarkiainen 1986, 181, but, as far as I can see, it does not appear anywhere on the letter itself. However, the following letter, dated 2nd March, suggests indeed that the preceding one had been written a day or a couple of days before.

${ }^{13}$ Zacharias Klingius (1603-1671) was a bishop and a Court chaplain. He taught theology in the Stockholm Gymnasium for several years.

14 The year is not indicated, but as Lumen Chronographicum was published 1664, it must be either 1663 or 1664 .

${ }^{15}$ Nicolaus Salanus (1618-1671) was a priest. In the Gymnasium he first taught Greek, later theology. 
transcription of a minor work he is occupied with. ${ }^{16}$ There are two circumstances that make him repeat his wish: on one hand, he has heard of some less worthy persons who aspire to the money; on the other hand, he wants to help a printer from Gothenburg, Amund Grefve, ${ }^{17}$ in moving his little press to Stockholm and thus to divide the sum between the two. He has no doubts that he will succeed, if De la Gardie helps him - just as he had done in 1663. Widekindi also expresses his deep discontent with the Gymnasium, mentioning that he has already voiced his opinion to Mr. Biörnklow, ${ }^{18}$ as De la Gardie had asked him to. He is eager to get a better position, since he has been watching the success of so many of his equals during the last ten years.

\section{Letter 8, 8th May 1665, Swedish}

Widekindi thanks De la Gardie for the new position he has been promoted to, "Charge på Cantzlie Staten”. Then he expresses his wishes and views concerning the organisation of the printing house, the reformation of the Gymnasium and a reward for his assistants.

\section{Letter 9, 16th November 1666, Swedish}

Widekindi is almost ready to proceed to what is now his direct duties, i. e. to writing histories, but asks De la Gardie for a respite, so that he may finish what he had begun before. Afterwards he is going to occupy himself with what De la Gardie has asked for: "the famous actions of your late father in the Muscovite war". He is also eager to write annals, covering the years from the death of Gustav I (i. e. 1560) to his own time, in Swedish with a Latin compendium. He has already prepared some extracts for this work. The letter ends with a traditional plea for money: Widekindi has not yet been paid anything in the Chancellery and asks De la Gardie to keep his salary in the Gymnasium.

Letter 10, undated (apparently about 1670, rather later than earlier), Swedish

Widekindi asks for 200 silver daler as a reward for his assistants. He is working on $A d$ ditamentum to the history of Gustav I, ${ }^{19}$ some additions to the history of King Erik's and King John's rule, ${ }^{20}$ and the history of Gustav Adolf's first quinquennium. ${ }^{21} \mathrm{He}$ is almost completed with them.

\section{Letter 11, 15th March 1672, Latin (see Appendix)}

Widekindi begs pardon for not talking to De la Gardie personally, as he was occupied with the burial of his brother. He has followed De la Gardie's order and erased the genealogical appendix from the Latin version of his book (this appendix put into doubt the right

16 We may suppose that it introductio in Lumen Chronologicum.

17 Amund Nilsson Grefwe (d. 1677) is known as the first printer in the city of Gothenburg.

18 Mattias Biörenklou (1607-1671) was a diplomate and a councilor of the Realm. He was one of the key figures in Swedish political life in the 1660s.

19 This work was published in 1672. Its full title runs as follows: Additamentum, eller Tilökning på någre tänckwärdige stycker som synas feela vthi Konung Göstaffz den I. Historie, hwilken aff Erick Göranszon Tegel vthförligen, och aff Aegidio Girs summewijs författat är.

20 Apparently never published.

21 The plan to write the entire history of Gustav Adolf's reign was never fulfilled. The opening part of it was published posthumously, in 1691, as Then fordom stormächtigste... herr Gustaff Adolphs den andres och stores Sweriges, Götes och Wändes etc. konungs Historia och lefwernes beskrifning, then första deel. A large part of the edition was confiscated and destroyed by the authorities after the protests from Danish and Russian diplomates concerning certain passages in the book. See Wadén 1959. 
of the Romanov dynasty to the Russian throne). ${ }^{22} \mathrm{He}$ mentions that he wrote Historia in Latin first, and then translated it into Swedish, hastily and with the help of some other people. He should have polished it better, but he paid more attention to the factual truth and also thought that the style of the Swedish text should be simpler. The Swedish text may be improved in the second edition, he says. The greatest difficulty during the work was the lack of sources, although Widekindi has read countless letters, diaries etc. He tried to be moderate and not to make too many judgments. In relating speeches and letters he rarely digresses from the actual words of historical figures and never from their opinions. Finally, Widekindi mentions his difficulties with printing his other books - the additions to the history of Gustav I and the history of Gustav Adolf's reign - and asks De la Gardie for help.

From this small collection of letters we get extremely important information on how Historia was written and some indications on when it was written.

The fact that the Swedish text is a translation from Latin, as clearly indicated in the last letter, is of fundamental importance for any philological analysis of the work (not to mention that it may here and there be important from a historian's point of view). Unfortunately, it has been ignored in the recent research. The editors of the Russian translation call the Latin text "translation" several times, ${ }^{23}$ Tarkiainen always refers to (and quotes) only the Swedish version in his works, and Stina Hansson has not included it into her list of translations into Swedish in the 17th century. ${ }^{24}$

Westrin lets the information that the work was first written in Latin be followed by a somewhat misleading statement: "The Latin version is hardly more than a compendium of the Swedish one". ${ }^{25}$ Strictly taken, this claim is absurd. It suggests that Widekindi, after having written the Latin text and translated it into Swedish, took the Swedish text as the base for writing a "compendium". It is not only general considerations that make such a theory look strange, but also the texts themselves. Wherever we know some Latin source of Widekindi, its text is repeated in the Latin version not only word-for-word, but sometimes with striking similarities in punctuation, ${ }^{26}$ as irregular as it was in the 17th century, whereas the Swedish text may here and there be abridged. ${ }^{27}$ Moreover, the Swedish version, taken as a whole, proves to be a result of a translation made hastily and not "polished enough", as Widekindi says himself. Already in the preface one may notice the "effter gifwin Orsak" 28 that is supposed to mean "after a reason had been found", with a participial construction as impossible as the English "after given reason" in this sense, but easily understandable if one bears in mind the expression "data causa" in the full Latin title of the work (Historia belli Sveco-Moscovitici Decennalis, quod... primum adversus Rebelles

22 This difference between the two versions has been noted in Kovalenko et al. 2000, 559.

23 Kovalenko et al. 2000, 545, 559, 560. Helander 2004, 187, 197 also mistakenly calls the Latin text "translation", but the context may allow him to do so: he is talking about the Latin equivalents for modern (Swedish) terms.

${ }^{24}$ Hansson 1982, 239-301.

25 Westrin 1921, 264.

${ }^{26}$ Compare, for instance, the parts of the passage on Cossacks (pp. 346-350) taken from Th. Ziegler's Theatrum Vitae Humanae (p. 4354) with the source indicated.

${ }_{27}$ Compare e. g. the excursus on Pskov in Latin (pp. 304-308), almost entirely sewn up of passages from D. Chytraeus and R. Heidenstein, and in Swedish (pp. 373-379) versions.

${ }^{28}$ Förtalet, s. [2]. 
et Lithuanos, mox Polonos, tandem data causa contra ipsos Moscovitas... varia fortuna ab anno seculi hujus septimo, in decimum septimum gestum, et ardua pace compositum est). Another example where the source language is obvious may be found in book 3 (p. 78). The Latin ablative absolute "quo facto", introducing a sentence with "nos" as supposed subject, is quite normal, whereas the Swedish text (p. 98) goes: "Hwilcket när thet war skedt äre wij...". The relative pronoun "hwilcket" could have been the subject - but the translator has noticed the following words, put the demonstrative "thet" as the correspondent to "quo" and made "wij" the subject; "hwilcket" hangs loosely and should be expunged. Examples of this and other types are so numerous that they would have been indeed enough for us to see which of the texts was written first, if we had not learned it from the author himself.

If we have to understand Westrin's term "compendium" in a more general sense, i. e. that the Latin text is simply shorter than the Swedish one, the statement is still not quite correct. The Swedish version is technically twice as long as the Latin one, but in the Latin text books 9 and 10 are simply missing. If we take only the first eight books, they cover 431 pages in the Latin edition and 562 pages in the Swedish one. The layout is similar: about 1200 characters per page in both versions. Taking into account the structural differences between two languages, the ratio looks not far from perfect: if the versions were identical, we would arrive at ca. 530 pages of Swedish text. ${ }^{29}$ However, one should keep in mind that there are many (although usually short) passages missing in either version, so this sort of arithmetic is almost pointless.

To sum up, the original complete text - the draft written by Widekindi himself in Latin - is lost. What we have is, on one hand, its inaccurate Swedish translation made by several persons, and on the other hand, its incomplete and slightly revised printed Latin version. It is the latter that should be the primary object for any philological analysis of the work.

So much for the "mechanism". What do we know about the chronology? As the text was translated into Swedish "hastily", we may cautiously put the translation around 1670. Why was it translated at all? Probably it has something to do with Magnus Gabriel De la Gardie's political views: he is well-known not least for promoting a stronger position of the national language. ${ }^{30}$ Probably De la Gardie expressed at some point a wish that the work would appear in both languages (not knowing that its draft had already been written in Latin). It will not be too bold to assume that he did so in response to letter 9, which could suggest such an idea to him.

The assumption that De la Gardie approved the publication of Historia after Widekindi's letter in November 1666, fits quite well into the political situation of the time. The tension between Sweden and Russia grew steadily during the second half of the 1660s and up to 1671, and Magnus Gabriel De la Gardie was the main advocate of an aggressive policy. ${ }^{31}$

So, the publication of the work must have served De la Gardie's political goals. However, what Widekindi had in mind, at least initially, during its composition, was the glorifi-

${ }^{29}$ I have taken eight short passages (one from each book) which do not contain any serious discrepancies between the versions, and compared the number of characters. 7395 characters in the Latin text correspond to 9088 in the Swedish one, i. e. the Swedish text is ca. 1.23 times longer.

30 See e. g. Hansson 1984, 39-40.

31 See Kovalenko et al. 2000, 533-540. 
cation of his patron's father. This is what we learn from letter 9, and also earlier, from letter 5, written in March 1663. When did Widekindi actually start his work? The first explicit mention of Historia may be found in letter 3 (July 1662). But it may be proved that the work began even earlier. Let us go back as far as to letter 1 .

Unfortunately, we cannot suggest that the transmissa pagina, sent together with the letter as a "trailer" to some of Widekindi's works, had to do with Historia. The possibility is not to be excluded altogether, but it seems unlikely for three reasons. Firstly, Widekindi had several projects at the same time, so it may have been, for instance, Lumen Chronologicum. Secondly, if it was Historia, Widekindi did not need to "confess" in which language it had been written, eleven years later. Finally, Widekindi mentions the transmissa pagina just after having said that he had abandoned the thought of describing Swedish-Polish relations, and we know that he regarded the Muscovite war as an integral part of these. In the preface to Historia Widekindi writes: "Hoc... obtineam... parte laboris confecta viam mihi parasse ad bellum Sveco-Polonicum describendum, quod hoc antecessit, excitavit, fovit et sequutum majori animorum offensa... suspensum subinde induciis, dilatum tractationibus, tandem in seculo hoc... usque ad sexagesimum $<$ sc. annum $>$ desaeviens, optata pace compositum est". The Muscovite war is pars laboris, not a different subject.

Transmissa pagina is consequently hardly to be put in connection with Historia. But there is still an indication that by 1661 , Widekindi had already made remarkable progress in writing the history of the Muscovite events.

Talking about his original project (the one on the history of Swedish-Polish relations) in the first letter, Widekindi describes it as "opus causa grave, consilijs multiplex, fortuna varia gestum". A very similar wording may be found in the preface to Historia (p.3): "Opus nascitur causa grave, consiliis multiplex, difficile judicio, animorum affectibus, et rerum eventu varium: neque hactenus ex proposito et plano a quoquam tentatum". It has been pointed out ${ }^{32}$ that it is a well-veiled allusion to the beginning of Tacitus' Histories (1, 2): "Opus adgredior opimum casibus, atrox proeliis, discors seditionibus, ipsa etiam pace saevum". Does the similarity between the letter from 1661 and the preface published in 1672 prove that Widekindi was working on Historia as early as in 1661? Not necessarily: he could have coined the line earlier and liked his invention so much that he put it in on every fitting occasion. But fortunately we know that it was not Widekindi who coined it. The words are taken from a draft to a historical sketch on Swedish-Polish relations written by Axel Oxenstierna in 1620s and partially extant to our days (Oxenstierna 1888, 239-246). It was extensively used by Widekindi in the first book of Historia and actually forms a basis for it. ${ }^{33}$ In this case the original (Oxenstierna's) text goes: "Opus adgredior causa grave, consiliis multiplex, difficile effectu atque eventu varium, neque hactenus a quoqvam tentatum".

The fact of using the draft of Oxenstierna draws our attention to another piece of information given by Widekindi in the first letter: from the middle of the 1650s he took care of Axel Oxenstierna's library. ${ }^{34}$ We know ${ }^{35}$ that the main part of this book collection

${ }^{32}$ Helander 2001, 42.

${ }^{33}$ See Oxenstierna 1888, 244 n. and Almquist 1907, XVI.

${ }^{34}$ In the title of his poem on the death of Johan Oxenstierna Widekindi calls himself "Eloq. et Hist. P. et Biblioth. Oxenst." - thus he still was librarian in 1659, when the poem was published. There is also evidence that he had access to the book collection as late as in 1666, see Oxenstierna 1888, XI n.

${ }^{35}$ Carlander 1904, 56-58; Oxenstierna 1888, XI. 
was until the 1670's held in the castle of Tidö, not far from Västerås; in 1732, a catalogue presumably describing the collection was published under the title Catalogus librorum, qui in bibliothecis illustrium qorundam virorum, hoc tempore reperiuntur, et Holmiae vel simul, tota bibliotheca, vel separatim per partes, indigenis et exoticis, jam nunc usque ad finem mensis junii anni subsequentis: venduntur.

Indeed, it turns out that this catalogue contains quite a few of the printed sources used by Widekindi in Historia, ${ }^{36}$ namely:

- Descriptio Sarmatiae Europeae by A.Guagnini (1581) - p. 45, N 379 in the catalogue

- Theatrum vitae humanae by Th. Zwinger (1604) - p. 67, N 568

- Europa by E. S. Piccolomini in his Opera omnia (1571) - p. 91, N 735

- Preussische Chronica by C. Schütz (1599) - p. 103, N 826

- Commentariorum Chotinensis belli libri III by J. Sobieski (1646) - p. 147, N 212

- De optimo statu libertatis libri II by Ch. Warsevicius (1598) - p. 165, N 379

- Mußkowitische Chronica by P. Petrejus (1620) - p. 197, N 612

- De bello Moscovitico Stephani Regis Poloniae commentariorum libri VI by R. Heidenstein (1588) - p. 233, N 874

- Exotericarum exercitationum libri XV by J. C. Scaliger (1576) - p. 373, N 600

- Meditamenta pro foederibus by E. von Weyhe aka W. de Ehrenberg (1641-42) p. $401, \mathrm{~N} 877$

Especially important is the presence of Warsevicius (apparently quite a rare book) and of the German version of Petrejus, while the catalogue does not contain the Swedish one (published in 1615) - and it is just the German version Widekindi refers to (on p. [448] of his Latin text).

One of the main sources of Historia (especially for books 3 and 4 ) is missing in this list, namely S. Kobierzycki's Historia Vladislai Poloniae et Sueciae Principis - but the reason is quite obvious: Axel Oxenstierna died 1654, a year before the publication of Kobierzycki's work. Probably Widekindi studied it later, in the 1660s. An important point is, however, that Widekindi had accomplished a great deal of work already in the middle or in the second half of the 1650s.

To sum up, the letters of Widekindi provide us with priceless information on the origins of Historia and allow us to draw an outline of what further research on this impressive piece of Swedish Neo-Latin literature should look like. First of all, the Latin text, a slight revision of the original draft, should be the primary object of the studies in stylistic, rhetorical and literary aspects of the work. Such studies are, though, less relevant (or even irrelevant, in certain cases) when it comes to passages loaned directly from other sources - thus the starting point is to look for these sources. The catalogue of Oxenstierna's library, containing a lot of both Rossica ${ }^{37}$ and Polonica, may provide us with some new discoveries in this respect. Secondly, the Swedish text (apart from books 9 and 10) is mostly interesting from the linguistic point of view, i. e. as a translation. It may be analyzed and compared with other Swedish translations from the 17th century, e. g. in terms of the

\footnotetext{
${ }^{36}$ I'm going to treat this subject elsewhere, as the problem of Widekindi's printed sources seems to have never been systematically studied.

37 Cf. Tarkiainen 1969-70, 118-119.
} 
recently released TRIX-method. ${ }^{38}$ An especially tempting question to embark on is, of course, whether it is possible to tell parts of text translated by different persons apart from one another. Finally, substantial differences between the two versions should be treated more thoroughly. ${ }^{39}$ We know from Widekindi's letter that at least one of them was due to De la Gardie's opinion which he expressed after having read the Swedish edition - could this be not the only case of the patron's influence on the Latin edition?

The research goes on. Historia itself is not less fruitful in confronting a scholar with interesting philological problems than these few letters that shed light on the history of its creation.

\section{Appendix}

Illustrissime Celsissimeque Domine, Regni Sv. Cancellarie, Patrone Summe.

Ignosce, obsecro, Gratiosissime Domine, quod coram Celsissimam Excel $<$ len $>\mathrm{t}<\mathrm{ia}>\mathrm{m}$ tuam non adeam, cum hisce diebus ex lege mortalitatis fraternis exeqvijs valde occupatus sim. Interim contestari iussit obseqvij debitum, me Literis Illustr. Excellentiae Tuae decenti veneratione acceptis, illico paruisse, et ex opere Moschovitico atque adeo omni memoria erasisse Appendicem illam genealogicam. Certum quidem est, Theodorum Michaelovizium tunc temporis nulla mentione consangvineitatis vel affinitatis cum magna Basilidum familia, sed fortuita electionis sorte primum a Cosacis proclamatum, et deinde quod in Adolescente mitis et Pacifici animi, in matre Prudentiae et magnanimitatis, in Patre (qui Patriarcha tunc captivus apud Polonos detinebatur) acris in gentem Polonam odij signa comparerent, a Bajoris in Magnum Ducem confirmatum fuisse: Certum quoque est, in Stolboensi tractatu, solenni cessione Livoniae, Careliae, et Ingriae, non usurpasse titulum illum, Plurium versus occidentem ditionum Dominum, sed posteriori tempore, quam commemorationem cum tempora non ferant, nec me in his nimis curiosum esse deceat, lubenter sapientissimo judicio tuo acquiesco, volens veritatem aeterna potius oblivione obrutam, quam cum periculoso fato luctari.

In reliquis, quod stylum et materiam attinet, fateor Romana lingua me primum historiam consignasse, vnde partim mea, partim (propter festinationem et impedimenta) aliorum cura in Sveticum idioma translata est, quod etiam, non diffiteor, melius expoliri et potuisse et debuisse, sed rerum documentis conquirendis magis intentus, nihil cultui et nitori dans, malebam stylum populari et quo vulgus hominum loquitur modo fluere, quam aliquid verborum flosculis ambituique dare, putans omnem simplicis et ingenuae veritatis gratiam a Svecico sermone perire, si multum ornamentis litaretur. quae minus concinne, clare aut apte posita possunt secunda editione emendari, et interim lumen a Latino textu, qui fulgidior, habere.

Quod res et materiam attinet, optassem, pleniori momentorum explicatione deduci potuisse. Sed, sub Regibus CAROLO GUSTAVOque arduis negocijs occupatissimis, cum nulla diaria, nulla ferme protocolla, aut Senatus consulta rite descripta extarent, paucae relationes integrae, acta comitiorum et deliberationum multa ex parte mutilata, ducum et militum literae variae, omnes qui interfuere mortui, oportuit me, illis quae haberi potuere, monumentis contentum fuisse. excussis omnibus loculis, perlectis innumeris literis, qvas

38 See Wollin 2014 .

39 The characteristic of these differences given in Kovalenko et al. 2000, 559-560 is somewhat superficial. 
satagebam, circumstantias plures clarioresque reperire non poteram. In judicijs ferendis volebam quidem parcus cautusque esse, quam profluens et largus, sed interim ea parrhesia uti, quae historicum deceat, quam et ratio tunc temporis ac status dictabat, et qua maximos viros, incomparabilem Parentem Tuum, aliosque duces et legatos usos fuisse video, extra quorum sensa nunqvam, raro verba vagatus sum. Si in aliquibus, hoc primo specimine, aberravi, humilime rogo, ut Illust. Excellentia Tua pro singulari sua humanitate benignissime interpret< $<$ et $>$ ur...

Denique devotissime veneror illa favoris tui ac patrocinii benignissima promissa, quae nisi diu mihi affulsissent, iam dudum difficiles hos labores deprecatus essem, qui utcunque tractentur, semper obnoxij: Nihilque maiori contentione rogo, ut si continuandi sunt, cum vita brevis ac memoria rerum fugax sit, qvam ut adminicula absolvendis suppeditentur. Nam et scribam quem superiori anno mihi adiunxi, nunc amisi, nec typographi proprijs sumptibus additamenta Gustavi Ii Historiae, aut hoc quinquennium primum Gustavi Adolphi excudere volunt, nec ipse, non rite soluto salario, sustineo. Itaque humilime et obnixe rogo, ut illustriss. Excell. Tua, quam honos et sera annalium gloria per literas in orbe nostro amplificatas manet, dignetur obstaculis remotis, taedijsque hisce laborum sublatis, destinata ad optatos successus promovere. Nam ut cito perficere, ita cito defungi cupio.

Celsissimae Excellentiae Tuae

humilimus observantissimusque cliens

Johan. Widekindi

Holm. 15. Mart. 72.

\section{References}

Almquist H. Sverge och Ryssland 1595-1611: Tvisten om Estland, förbundet mot Polen, de ryska gränslandens eröfring och den stora dynastiska planen. Uppsala, 1907.

Carlander C. M. Svenska bibliotek och exlibris. 2. Stockholm, 1904.

Edlund S. M. G. de la Gardies inrikespolitiska program 1655: ett bidrag till den ståndspolitiska och pedagogiska debatten under 1600-talet. Lund, 1954.

Hansson S. "Afsatt på swensko": 1600-talets tryckta översättningslitteratur. Göteborg, 1982.

Hansson S. Svenskans nytta, Sveriges ära: litteratur och kulturpolitik under 1600-talet. Göteborg, 1984.

Helander H. Neo-Latin Studies: Significance and Prospects. Symbolae Osloenses 2001, 76, 5-102.

Helander H. Neo-Latin Literature in Sweden in the Period 1620-1720. Stylistics, Vocabulary and Characteristic Ideas. Uppsala, 2004.

Kovalenko G.M., Khoroshkevich, A.L., Pliguzov, A.I.Apologiia Iukhana Videkinda, in: V.L.Ianin, A. L. Khoroshkevich (eds.), S. A. Anninskij, A. M. Aleksandrov (transl.). Widekind, J. Istorija desiatiletnej shvedsko-moskovitskoj vojny. Moskva, 2000 [Kovalenko, G. M., Khoroshkevich, A. L., Pliguzov, A. I. An Apology of Johan Widekindi, in: Widekind, J. The History of the Swedish-Muscovite Ten-Years War. Moscow, 2000].

Oxenstierna 1888 = Rikskansleren Axel Oxenstiernas skrifter och brefvexling. Afdelning 1. Band 1. Historiska och politiska skrifter. Kungliga Vitterhets historie och antikvitets akademien, Stockholm, 1888.

Tarkiainen K. Västeuropeiska Rysslandsskildringar i svenska 1600-tals bibliotek. Studier i Rossica externa. Lychnos, 1969-1970, 97-119.

Tarkiainen K. Se vanha vainooja. Helsinki, 1986.

Wadén J. Historisk censur under det karolinska enväldet. Kring beslaget pa Johan Widekindis historia om Gustaf II Adolf. Karolinska förbundets årsbok, 1959, 33-82.

Westrin J. Th. Widekindi. Nordisk familjebok, 1921, 32, 263-265.

Wifstrand Schiebe, M. Annius von Viterbo und die schwedische Historiographie des 16. und 17. Jahrhunderts. Uppsala, 1992. 
Wollin L. Den osedda doktrinen. Något om att skriva en svensk översättningshistoria. Kungliga Humanistiska Vetenskaps-Samfundet i Uppsala. Årsbok, 2014, 27-51.

For citation: Vetushko-Kalevich A. Biligual Writings on Bilingual Writings: J. Widekindi's Letters to M. G. De La Gardie. Philologia Classica 2016, 11(2), 289-300. DOI: 10.21638/11701/spbu20.2016.208

\section{НА ДВУХ ЯЗЫКАХ О ДВУЯЗЫЧНОМ ТЕКСТЕ: ПИСЬМА ЮХАНА ВИДЕКИНДА МАГНУСУ ГАБРИЭЛЮ ДЕЛАГАРДИ}

\section{Арсений Анатольевич Ветушко-Калевич}

Собрание писем Юхана Видекинда Магнусу Габриэлю Делагарди, хранящееся в Государственном архиве Швеции, до сих пор оставалось без должного внимания в исследованиях, относящихся к истории создания «Истории десятилетней шведско-московитской войны», главного труда Видекинда, в котором описываются события Смутного времени и Ингерманландской войны. Особенно важно в этом отношении последнее из 11 писем, датированное 15 марта 1672 года и посвященное почти исключительно «Истории». Из него следует, что первоначально текст книги был написан по-латыни (хотя шведская версия была опубликована первой). Шведское издание 1671 года - перевод, поспешно выполненный Видекиндом и несколькими его помощниками, а латинское издание 1672 года - отредактированный и неполный текст оригинала. Из другого письма известно, что Видекинд начал работу над книгой еще до 1661 года. Его основной целью, ясно обозначенной в письмах, было прославление Якоба Делагарди, отца его покровителя. Но М. Г. Делагарди, которому долгое время было известно о проекте историографа, стал оказывать ему помощь в публикации «Истории» только в 1666 году (или позднее), - вероятно, потому, что она стала вписываться в его внешнеполитическую программу. То обстоятельство - также известное из писем, - что в середине 1650-х гг. (или начиная с этого времени) Видекинд имел доступ к библиотеке канцлера Акселя Оксеншерны, а также использование им черновиков Оксеншерны при написании первой книги «Истории» позволяют думать, что со многими своими источниками Видекинд познакомился именно там. Каталог книжного собрания Оксеншерны подтверждает такое предположение.

Ключевые слова: Смутное время, Ингерманландская война, шведская новолатинская литература, историография XVII в., Россика, Юхан Видекинд, Магнус Габриэль Делагарди.

Received: 15.08 .2016

Final version received: 14.10 .2016 